\section{De 1919 a 1923, os primeiros momentos do rádio no Brasil'}

Luiz Artur FERRARETTOP

Resumo: Estudo historiográfico a respeito dos primeiros momentos do processo de delineamento do rádio como meio de comunicação no Brasil. Registra, deste modo, a passagem de uma abordagem comunicacional ponto-ponto - a radiotelegrafia, a radiotelefonia e a radiocomunicação - para outra ponto-massa, que gradativamente vai adotar a denominação rádio. Faz, assim, a descrição analítica do Rádio Clube de Pernambuco, da Exposição Internacional do Rio de Janeiro e da Rádio Sociedade do Rio de Janeiro entre 1919 e 1923. Objetiva, portanto, apontar elementos para a valorização dos principais protagonistas históricos deste processo, integrantes de estratos sociais identificados com a burguesia.

Palavras-chave: Rádio no Brasil; História do rádio; Rádio Clube de Pernambuco; Exposição Internacional do Rio de Janeiro; Rádio Sociedade do Rio de Janeiro.

\section{De 1919 a 1923, los primeros momentos de la radio en Brasil}

Resumen: Estudio historiográfico a respecto de los primeros momentos del proceso de definición de la radio como medio de comunicación en Brasil. Registra, de este modo, el pasaje de un abordaje comunicacional punto

1 Versão de artigo apresentado no Grupo de Pesquisa Rádio e Mídia Sonora, dentro do XII Encontro dos Grupos de Pesquisa em Comunicação, evento componente do XXXV Congresso Brasileiro de Ciências da Comunicação, realizado na Universidade de Fortaleza, Fortaleza (CE), em setembro de 2012.

2 Professor da Faculdade de Biblioteconomia e Comunicação da Universidade Federal do Rio Grande do Sul., em Porto Alegre. Formado em Jornalismo pela mesma instituição (1986), onde também concluiu o mestrado (2000) e o doutorado (2005) no Programa de Pós-graduação em Comunicação e Informação. Autor de Rádio - O veículo, a bistória e a técnica ( $3^{a}$ edição em 2007), Rádio no Rio Grande do Sul (anos 20, 30 e 40): dos pioneiros às emissoras comerciais (2002) e Rádio e capitalismo no Rio Grande do Sul: as emissoras comerciais e suas estratégias de programação na segunda metade do século 20 (2007). Na Sociedade Brasileira de Estudos Interdisciplinares da Comunicação (Intercom), coordenou o Grupo de Pesquisa Rádio e Mídia Sonora (2007-2010). Endereço eletrônico: luiz.ferraretto@uol. com.br. -punto - la radiotelegrafía, la radiotelefonía y la radiocomunicación - hacia otro punto-masa, que gradualmente va a adoptar la denominación radio. Se hace, así, la descripción analítica del Radio Club de Pernambuco, de la Exposición Internacional de Rio de Janeiro y de la Radio Sociedad de Rio de Janeiro entre 1919 y 1923. Objetiva, por tanto, apuntar elementos para la valorización de los principales protagonistas históricos de este proceso, integrantes de estratos sociales identificados con la burguesía.

Palabras clave: Radio en Brasil; Historia de la radio; Radio Club de Pernambuco; Exposición Internacional de Rio de Janeiro; Radio Sociedad de Rio de Janeiro.

Do final dos anos 1910 até a segunda metade da década de 1920, o rádio vai gradativamente, no Brasil, constituir-se como meio de comunicação específico. Reprisando no país o ocorrido em paralelo nos Estados Unidos, trata-se, em realidade, de uma alteração no uso da tecnologia envolvida e, efetivamente, na ideia do que seja rádio: o antes pensado para interligar, sem fios, dois pontos, ambos enviando e recebendo mensagens, passa a ser empregado para o tráfego de informações, por ondas eletromagnéticas, de uma estação emissora para ouvintes distribuídos nos mais diversos locais. Como na América do Norte, este processo ocorre dentro da pequena parcela da elite com condições socioeconômicas para ter acesso a equipamentos então muito caros e compreender as potencialidades do rádio, o que, no caso brasileiro, reveste-se de boa dose de idealismo, por um viés educativo-cultural associado, no imaginário, a noções de moderno e de progresso. Tais características estão presentes nos entusiastas que se reúnem em torno do Rádio Clube de Pernambuco e da Rádio Sociedade do Rio de Janeiro. Alguns deles, em especial, no caso dos da então capital federal, vão ter o seu interesse despertado ou reforçado durante a Exposição Internacional do Rio de Janeiro.

Como já demonstrado anteriormente (FERRARETTO, 2011), considera-se, portanto, a necessidade de diferenciar duas modalidades comunicacionais que usaram como designativo o termo rádio. Este, cronologicamente, primeiro, relaciona-se à transmissão de mensagens formadas por sinais em Código Morse - a radiotelegrafia - ou por voz - a radiotelefonia e, no caso do emprego desta última em embarcações ou em manobras militares, a radiocomunicação -, todos pensados para a conexão ponto-ponto. Neste sentido, em inglês, "radio", uma apropriação do vocábulo latino "radio" (JAMIESON, 1828, 
p. 452), corresponde a "wireless" - em português, sem fio. Como registra o Oxford English dictionary (2009), a palavra passa a ser usada em relação ao meio específico somente em 1922, identificando uma forma de comunicação ponto-massa, em que a estação posiciona-se apenas como emissora - daí a óbvia sinonímia estabelecida entre estas duas palavras -, tendo como receptores aqueles, de início, identificados como "amadores da radiofonia" ou "da radiotelefonia" -, "radiófilos" ou "sem-filistas" (FERRARETTO, 2009, p. 97), os ouvintes de hoje.

\section{O rádio e as ideias de moderno, progresso e ci- vilização}

De modo semelhante ao que ocorre no final do século 20 com a internet, o rádio aparece, de início, como uma forma de colocar o indivíduo em contato com o mundo, pelo menos, para os que possuem recursos econômicos, garantindo seu acesso ao novo meio. São eles que vão formar, quase como um hobby, clubes e sociedades dedicadas à escuta e à transmissão, base das primeiras estações brasileiras. Este tipo de entidade tem a finalidade, como salienta Maria Elvira Bonavita Federico (1982. p. 33), "além de divulgar os conhecimentos sobre o rádio, de angariar novos adeptos e até mesmo propiciar-lhes treinamento para se constituírem pelo menos em radioescutas". Os dados existentes indicam semelhanças entre estes pioneiros:

São eles entusiastas com conhecimento da tecnologia radiofônica e outros ligados ao ensino e, mesmo, ao comércio, muitos mantendo boas relações com a classe política. Cada sócio tem de pagar, além da joia inicial, uma mensalidade $[\cdots]$.

As transmissões ocorrem, em geral, à noite e em dias esparsos, sem uma continuidade entre um conteúdo e outro. Assim, à conferência científica seguemse minutos de silêncio até que alguém, como se estivesse em um sarau em uma típica casa burguesa, apresente talvez um número de piano ou de violão, podendo ocorrer mesmo a afinação do instrumento à frente do microfone. (FERRARETTO, 2009.p. 97-8).

No imaginário desta parcela da elite brasileira, a possibilidade de captar irradiações provenientes, inclusi- ve, de outros países reveste-se de uma ideia de moderno que Renato Ortiz (1994. p. 32) identifica em outros dois fatos da época, a crescente consolidação do cinema e a urbanização do Rio de Janeiro, a então capital do país:

Em ambos os casos, [...] a ideia de mo-
derno se associa a valores como pro-
gresso e civilização; ela é, sobretudo,
uma representação que articula o sub-
desenvolvimento da situação brasilei-
ra a uma vontade de reconhecimento
que as classes dominantes ressentem.
Daí o fato de essa atitude estar intima-
mente relacionada a uma preocupação
de fundo, o que diriam os estrangeiros
de nós, o que reflete não somente uma
dependência aos valores europeus, mas
revela o esforço de esculpir um retrato
do Brasil condizente com o imaginário
civilizado.

Este "o que diriam os estrangeiros de nós" fica patente na organização e realização da Exposição Internacional do Rio de Janeiro, que vai comemorar o centenário da independência do Brasil em 1922. De um lado, apresenta a pretensa pujança nacional e, de outro, serve de mostruário ao progresso vindo do exterior. No caso do rádio, adapta-se às necessidades das indústrias eletroeletrônicas dos Estados Unidos em fase de expansão multinacional que, sem os rendimentos provenientes da produção voltada à Grande Guerra de 1914-1918, buscam novos mercados para garantir e ampliar seus níveis de lucro.

É dentro do seu contexto de classe social e de época que parcela da elite desperta para as potencialidades do rádio. Ao contrário do que vai ocorrer a partir da década de 1930, estes pioneiros fazem isto, em um primeiro momento, sem interesses preponderantemente econômicos ou políticos. As irradiações têm pretensão educativo-cultural, incluindo, além de música gravada e ao vivo, até mesmo palestras de cunho científico. Indo ao encontro de valores burgueses, expressões musicais mais populares como o samba encontram resistência para serem veiculadas. Predomina, basicamente, um associativismo idealista de elite misturado a certo entusiasmo tecnológico, embora quem faça rádio execute suas tarefas em um permanente amadorismo. Se não chega a ser aquele experimentar no sentido dado pela ciência, o que vale para os pioneiros parece ser a ideia de ter a experiência de. 


\section{A Exposição Internacional do Rio de Janeiro}

O lugar em si já indicava uma mudança. Na ponta do Calabouço, antes parte do morro do Castelo derrubado no ano anterior, começaram a surgir prédios e prédios, cada um deles representando um estado do Brasil ou uma "nação amiga", como vinham insistindo os organizadores e dava eco a imprensa. Não é de se admirar que o projetado para começar em 7 de setembro de 1922 e terminar em 31 de março de 1923 acabasse se estendendo até 24 de julho. De fato, o gigantismo da Exposição Internacional do Rio de Janeiro levaria alguns pavilhões a só serem finalizados depois do início oficial da feira. No meio de tantas atrações - apresentações culturais e artísticas, congressos científicos, desfiles patrióticos e paradas militares, mostras dos mais diversos produtos, parque de diversões, presenças de chefes de Estado... -, não é de se admirar também que a primeira demonstração pública de rádio passasse quase despercebida, embora saudada como novidade pelos jornais:

Foi, sem dúvida, a nota mais interessante das festas comemorativas do nosso centenário, a instalação dos telefones alto-falantes [...].

A marcha dos soldados, as vozes de comando, os discursos da inauguração da exposição e até as palestras do presidente com as altas autoridades eram transmitidas para o público pelos dois fones, aglomerando-se os populares em redor dos mesmos, para ouvirem, nos seus mínimos detalhes, tudo o que se passava no pavilhão das festas, na ocasião da cerimônia inaugural. (O JORNAL, 8 set. 1922. p. 10). ${ }^{3}$

Na noite deste mesmo 7 de setembro de 1922, os "telefones alto-falantes", forma utilizada na imprensa para identificar as singelas cornetas colocadas em alguns pontos da exposição, trazem aos pavilhões a ópera $O$ guarani, apresentada, a algumas quadras, no Teatro $\mathrm{Mu}-$ nicipal. As demonstrações integram o rol das novidades tecnológicas colocadas à disposição do público no estande dos Estados Unidos, um dos maiores da exposição. A respeito, já noticiava o jornal $A$ Noite, meses antes, reproduzindo material de divulgação distribuído pelos representantes daquele país:

3 Neste e nos demais registros de época, adaptou-se a redação original às atuais normas da Língua Portuguesa, corrigindo-se, ainda, alguns eventuais erros.
Comunica-nos a delegação dos Estados Unidos da América na exposição do centenário:

"As firmas, cujos produtos são mundialmente conhecidos, tomaram grandes espaços no edifício da Exposição Industrial Norte-americana, que, como se sabe, está sendo construído nesta capital para tomar parte conjuntamente com a Grande Exposição Internacional.

[...] O telefone sem fio, por meio do rádio, que, como se sabe, é a última invenção que está atraindo a atenção [...], será apresentado como um produto especial na exposição que fará a Westinghouse Electric and Manufacturing Company. As pessoas que visitarem a Exposição Industrial Americana, à praça Mauá, poderão permanecer próximo à exposição da Westinghouse e aí escutarem música e canto provenientes da estação central. Será uma novidade interessantíssima para quem não teve o prazer de ver, ainda, essa nova conquista da ciência. [...]" (A NOITE, 20 maio 1922, p. 6).

13

A expectativa comercial, que se depreende do release transcrito pelo jornal, vai acabar frustrada apesar de certo tom eufórico nos relatos da imprensa, talvez resultado também do trabalho dos public relations professionals a soldo das empresas estadunidenses. Conforme Jaime G. de Moraes ${ }^{4}$ (13 abr. 2010), a estação da Westinghouse, com $500 \mathrm{~W}$, instalada no morro do Corcovado e que recebeu o prefixo SPC, chega a ser captada, no dia 10 de dezembro de 1922, em Bernal, na província de Buenos Aires, na Argentina, aproximadamente a $2.000 \mathrm{~km}$ de distância. No entanto, terminada a exposição e não havendo comprador interessado, é desmontada e embarcada de volta para os Estados Unidos, passando a ser utilizada, a partir de 1924, pela WNYC, emissora ligada, então, à municipalidade de Nova Iorque. Moraes (16 abr. 2010) registra a montagem pela Western Electric, durante a exposição, de outra estação de potência idêntica no antigo prédio da Repartição dos

4 Colaborador da revista Antenna, periódico especializado em rádio e televisão, que, em sua origem, era órgão oficial do Rádio Clube do Brasil, uma das primeiras entidades a transmitir no país. Jaime G. de Moraes baseia-se em documentos e reportagens do acervo da publicação, além de outras fontes primárias. Em abril de 2010, vários posts no seu blog História do rádio descrevem as estações montadas para a Exposição Internacional do Rio de Janeiro. 
Correios e Telégrafos, na Praia Vermelha, que recebeu o prefixo SPE. Na época, chamam a atenção as instalações, em especial a enorme antena, composta por seis fios de cobre que atingem a altura de 150 metros, estrutura erguida graças a um cabo de aço estendido entre os topos dos morros da Urca e da Babilônia, uma obra de engenharia avistada a distância considerável. De acordo com Jaime Moraes (15 ab. 2010), os equipamentos da Western eram mais versáteis, permitindo um sistema de comutação rápida da transmissão de sinais em código Morse para a irradiação de áudio. A estação SPE, ao contrário da pertencente à Westinghouse, vai ser adquirida pelo governo federal em 1923. As irradiações de ambas as emissoras, no entanto, ocorrem em condições consideravelmente precárias:

Talvez por falta de comunicação entre as duas empresas que trouxeram equipamentos de rádio (Westinghouse e Western Electric), as frequências de operação eram próximas: $800 \mathrm{kHz}$ e 860 kHz. Como a recepção era feita por receptores de baixa seletividade, caso as transmissões fossem realizadas ao mesmo tempo, inevitavelmente os sinais seriam recebidos misturados. A solução foi transmitir em horários alternados ou então em dias alternados. (MORAES, 17 abr. 2010).

Uma semana após as transmissões durante a inauguração da exposição, o diário carioca O Jornal (14 set. 1922, p. 6) publica um comentário intitulado e assinado por "Um radiotelefonista", criticando a qualidade do sinal disponibilizado pela Westinghouse:

O serviço de transmissão de radiotelefonia da estação do Corcovado não está sendo feito com a precisão técnica que recomenda o nome da Westinghouse. Isso é, sem dúvida, pelo fato de terem colocado somente um receptor $[0$ microfone] no Teatro Municipal e esse mesmo junto ao ponto que é ouvido, com prejuízo para o efeito da transmissão e do cantor. A orquestra em certos momentos é abafada totalmente pelo canto, outra falha perfeitamente corrigivel.

A men ver, deviam ser colocados três receptores

5 Cabe lembrar que, não raro, integrantes da imprensa utilizavam este recurso para fazer críticas anônimas.



De modo geral, as demais irradiações também não parecem, pela qualidade técnica, ter chamado a atenção do grande público, como se depreende deste depoimento de uma testemunha daquelas transmissões, Edgard Roquette-Pinto, grande pioneiro do rádio no país:

É que, durante a Exposição do Centenário da Independência, em 1922, muito pouca gente se interessou pelas demonstrações experimentais de radiotelefonia então realizadas pelas companhias norte-americanas Westinghouse, na estação do Corcovado, e Western Electric, na Praia Vermelha. [...]. Creio que a causa desse desinteresse foram os alto-falantes instalados na exposição. Ouvindo discurso e música reproduzidos no meio de um barulho infernal, tudo distorcido, arranhando os ouvidos, era uma curiosidade sem maiores consequências. (BBC, 1988).

Em direção contrária a estas manifestações, chama a atenção uma notícia de difícil confirmação publicada pelo jornal The New York Times (30 mar. 1923):

CHICAGO, 29 de março - Uma transmissão de rádio proveniente da Exposição do Centenário da Independência brasileira, no Rio de Janeiro, foi captada por uma das estações do governo dos Estados Unidos, em Honolulu, a 8.000 milhas de distância [o equivalente a 13.400 km], estabelecendo um novo recorde. Anunciou, hoje, o escritório da Western Electric Company.

Mesmo sem as interferências radioelétricas de hoje, a informação soa exagerada, até por não se saber exatamente qual a qualidade do sinal recebido e durante quanto tempo esta sintonia foi possível. Cabe lembrar que a Westinghouse - como também a Western - já possuía estruturas de divulgação consideráveis, concentradas na busca de mercados promissores, entre os quais se des- 
taca, então, o Brasil. Exageros e frustrações à parte, as demonstrações conseguem fomentar ou reforçar a curiosidade em integrantes da elite a respeito das transmissões sonoras por ondas eletromagnéticas, cujo uso, graças a estas pessoas, vai se delinear cada vez menos como radiotelefonia ou radiocomunicação e cada vez mais como rádio.

\section{O associativismo idealista de elite}

A implantação do rádio no Brasil coincide com uma série de acontecimentos a demonstrar uma vontade modificadora presente na vida cultural, econômica, política e social do país. Neste quadro, o associativismo idealista de elite reflete, nos clubes e sociedades dos pioneiros sem-filistas, um grau de comprometimento com as ideias de moderno, progresso e civilização, mas - dentro dos limites expostos por Ortiz (1994. p. 32) -, muito relacionadas ao referencial estrangeiro: a Europa a perder influência e os Estados Unidos a ganhá-la.

Insere-se neste processo a própria Exposição Internacional do Rio de Janeiro. De fato, a ideia de vender um Brasil "com suntuosos stands para inglês ver e comprar” (NOSSO SÉCULO, 1980-1982, v. 2, p. 210) não era em si nova. Em 1908, o governo Affonso Penna, com a Exposição Nacional, já usara os cem anos da abertura dos portos brasileiros para buscar investimentos estrangeiros e apresentar um Rio de Janeiro saneado do ponto de vista da higiene pública e remodelado em termos urbanísticos. O Brasil havia entrado, deste modo, na onda das feiras, comuns desde meados do século 19 nos Estados Unidos, nas quais, além de tecnologia em si, difunde-se um tipo de sociedade em que o consumo e o lazer aparecem como objetivos centrais, encobrindo o jogo de produção e busca incessante de lucro inerentes ao capitalismo.

Há também todo um conjunto de acontecimentos identificado com uma pretensão transformadora da realidade nacional. Dos movimentos operários anarquistas, no início do século 20, à fundação do Partido Comunista do Brasil, em 1922. Da industrialização incipiente em São Paulo às transformações urbanas, das quais o maior exemplo é a capital federal, o Rio do Janeiro do "bota abaixo" da gestão do intendente ${ }^{6}$ Pereira Passos (1902-1906), derrubando casas pobres e cortiços para, no lugar, construir avenidas e boulevards, uma espécie de saneamento de classes sociais continuado por seus sucessores. Da Semana de Arte Moderna, redefinindo os parâmetros da cultura brasileira, em fevereiro de 1922, ao tenentismo que irrompe, meses depois, na tentativa de, pelas armas, refundar politicamente o país. (NOSSO SÉCULO, 1980-1982, v. 2, p. 225-233).

6 Cargo equivalente hoje ao de prefeito.
Neste contexto, o associativismo idealista de elite define-se organizado em clubes e sociedades e orientado por uma perspectiva cultural e científica dentro do quadro de valores da burguesia urbana em ascensão. A lhe intensificar o caráter elitista, além da origem social dos assim chamados radiófilos, aparecem os altos custos envolvidos: (1) na obtenção de uma licença para a escuta, uma particularidade de então; (2) no pagamento dos encargos para se tornar sócio da entidade responsável pela estação de rádio; e (3) na compra de receptores.

Maria Elvira Bonavita Federico (1982, p. 47) descreve as diversas taxas referentes às estampilhas a serem afixadas em requerimentos para o cumprimento de exigências burocráticas e legais junto a repartições públicas: uma de um mil-réis ${ }^{7}$ para o pedido ao Ministério de Viação e Obras Públicas, outra de um mil-réis para o atestado de idoneidade, outra de um mil-réis para o esquema de instalação a ser submetido ao Departamento de Correios e Telégrafos, e, por fim, mais uma de 600 réis referente ao conjunto destes documentos. A despesa com os aparelhos receptores, como observado em outra ocasião (FERRARETTTO, 2002, p. 37-9), também é proibitiva: uma simples galena, já montada, chega a custar, nos anos 1920, 35 mil -réis, enquanto um sofisticado receptor de três ou quatro válvulas atinge 400 mil-réis. Um exemplo dos valores pagos para a associação a uma destas entidades aparece, anos depois, na revista O Observador - Econômico e Financeiro (jul. 1938, p. 46), que descreve a situação inicial dos integrantes da Rádio Sociedade do Rio de Janeiro:

Os sócios efetivos pagam a joia de cem mil-réis para o fundo de reserva e contribuem mensalmente com a quantia de cinco mil-réis. Os associados pagam mensalmente uma cota variável, que é calculada dividindo-se as despesas pelo número de contribuintes dessa categoria.

Para situar o que significam, na época, estes valores, toma-se, como termo de comparação, a renda de um trabalhador urbano ou rural. Os dados a respeito são imprecisos, mas é possível estimar que um assalariado não ganhasse mais de 200 mil-réis. Conforme registro dos militantes anarquistas Hélio Negro e Edgard Leuenroth (apud NOSSO SÉCULO, 1982, v. 2, p. 88), em 1918, no campo ou na cidade, o salário mensal varia de 80 mil-réis a 120 mil-réis. O consumo mínimo de

7 Moeda vigente no Brasil até 30 de outubro de 1942.
15

Revista Brasileira de História da Mídia (RBHM) - v.3, n.1, jan.2014-jun/2014 - ISSN 2238-5126 
uma família operária de porte médio (homem, mulher e duas crianças) chega a 207 mil-réis e 650. Portanto, podese considerar que o rádio, de início, não se constitui em um passatempo barato. No entanto, dentro do quadro de valores das parcelas da elite responsáveis por sua introdução no país, aparece como elemento modernizante, de progresso e civilizatório. Sua popularização nas décadas seguintes, mesmo que em um viés comercial, bem diverso do propugnado pelos pioneiros dos anos 1920, irá comprovar esta ideia inicial.

\section{O Rádio Clube de Pernambuco}

No Brasil, a primeira entidade a reunir aficionados pelas possibilidades da transmissão de mensagens por ondas eletromagnéticas surgiu na cidade de Recife em 1919. No dia 6 de abril daquele ano, é fundado o Rádio Clube de Pernambuco, por um grupo de "amadores da radiotelegrafia", como aparece no estatuto aprovado algumas semanas depois, no dia 27 (RÁDIO CLUBE, 1919, f. 3). A singela atitude destes pioneiros liderados por Augusto Joaquim Pereira vai dar origem a uma das principais dúvidas históricas sobre os anos iniciais do rádio no país, ligada a qual seria, realmente, a entidade a instalar a primeira estação: o Rádio Clube de Pernambuco ou a Rádio Sociedade do Rio de Janeiro. A questão, portanto, passa por definir quem transmitiu antes conteúdo sonoro - conversação, conferências, debates, música etc. - em uma perspectiva ponto-massa e com que frequência o fez. De acordo com as referências existentes, boa parte das dúvidas advém: (1) da impossibilidade de enquadrar os pioneiros nordestinos, com certeza, como radioamadores, radiodifusores ou ambas as categorias; e (2) da fundação da entidade, em 1919, e de sua reorganização, quatro anos depois.

A principal fonte de referência a respeito da experiência inicial deste grupo de entusiastas é o texto Rádio Clube de Pernambuco - Notas sobre sua bistória (abr. 1984), redigido por Oscar Dubeux Pinto ${ }^{8}$, baseado em documentos do próprio Augusto Joaquim Pereira, e repassado, junto com estes, pelo autor à Fundação Joaquim Nabuco (Fundaj), de Recife. A partir deste material, Renato Phaelante da Câmara, da Fonoteca da Fundaj, reconstitui a trajetória inicial da entidade no livro Fragmentos da história do Rádio Clube de Pernambuco, lançado originalmente em 1994. De alguns documentos ali reproduzidos, é possível verificar uma intenção inicial voltada, de modo

8 O material de autoria de Oscar Dubeux Pinto reveste-se de importância por ter sido ele um dos mais ativos sócios na área técnica do Rádio Clube, entidade à qual esteve ligado do início dos anos 1920 até 1929. preponderante, à radiotelegrafia. No artigo $1^{\circ}$ do estatuto aprovado em 1919, consta a identificação dos integrantes do Rádio Clube como "amadores da radiotelegrafia" (RÁDIO CLUBE, 1919, f. 3). De fato, a entidade parece surgir voltada ao esforço de legalizar estações particulares deste tipo, então clandestinas, como indica a proposta - reproduzida por Phaelante da Câmara (1998, p. 36) que cada sócio deveria preencher e assinar no sentido de legalizar seu "posto radiotelegráfico". A respeito, o próprio Augusto Joaquim Pereira (apud PINTO, abr. 1984) observaria:

Devo dizer que as minhas atividades nessa ciência vinham de longe, podendo afirmar que antes de 1910. Havia uma mentalidade contrária a nossa mania. Éramos perseguidos, os nossos aparelhos apreendidos pela policia etc., porque se diria tratar-se de clandestinos no setor de comunicacões radioelétricas.

Cabe observar que, conforme a legislação vigente, a radiotelegrafia era privativa do governo. A organização de uma entidade de amadores voltava-se, assim, à defesa do que estes pioneiros consideravam seus direitos: ter acesso legal à possibilidade de transmitir e receber mensagens por ondas eletromagnéticas. A respeito, Oscar Dubeux Pinto (abr. 1984) reproduz trecho de um texto publicado por Augusto Joaquim Pereira no jornal $A$ Provincia, em 20 de abril de 1915: "Aqui em Pernambuco, já se conta em mais de uma dezena o número de amadores, por isso, pensamos, seria conveniente uma reunião, para, de acordo com os amadores de outros estados da União e depois da guerra, ser solicitada aos poderes competentes uma lei semelhante á inglesa ou americana [...]".

Sobre a transmissão sonora, Oscar Dubeux Pinto (abr. 1984) faz referências que apontam para a radiotelefonia ou para uma forma primitiva de rádio. Registra que Augusto Joaquim Pereira chegou a construir um pequeno transmissor de telefonia, de $5 \mathrm{~W}$ de potência, junto ao qual aparece em fotografia publicada na revista especializada estadunidense Radio Amateurs News, de novembro de 1924. No mesmo sentido, vai uma declaração atribuída ao próprio Pereira (apud PINTO, abr. 1984):

Afoitamente, usávamos os nossos transmissores e receptores de telegrafia e telefonia home made e, aos poucos, 
impondo-nos à boa amizade dos profissionais, oferecíamos para escuta aparelhos feitos por nós, melhores e mais eficientes do que os existentes [...] e, assim eles iam esquecendo a nossa clandestinidade.

Dubuex Pinto (abr. 1984) relata, também, que um dos sócios do Rádio Clube, Tito Xavier, "enfrentando a proibição legal, fez radiodifusão, irradiando música, sem se identificar, utilizando um transmissor por ele mesmo construído". Neste sentido, Renato Phaelante da Câmara (1998, p. 28) afirma que, ainda no início dos anos 1920, foram transmitidas "óperas, suítes, obras clássicas em geral", com discos emprestados pelos associados e buscando atrair novos adeptos que cresciam graças à disseminação de receptores de galena.

O próprio estatuto indica o compromisso do Rádio Clube com a vulgarização não só da telegrafia sem fios, mas também de "outras aplicações das ondas hertzianas", entre elas a "telefonia sem fios" (RÁDIO CLUBE, 1919, f. 3-4). Como indício significativo das intenções da associação que estava sendo criada, Phaelante (1998, p. 19) destaca o item D do artigo $2^{\circ}$ do estatuto: "A montagem de uma estação experimental de primeira ordem, onde possam ser estudados e aperfeiçoados os meios de transmissão sem fios do pensamento humano, já por sinais convencionais como os atualmente em uso na telegrafia, já pela telefonia" (RÁDIO CLUBE, 1919, f. 4).

Graças ao apoio financeiro de João Cardoso Ayres Filho, um dos principais proprietários de usinas de açúcar da região, o Rádio Clube de Pernambuco reorganiza-se em 1923. No ano anterior, havia se juntado ao grupo, Oscar Moreira Pinto, um ex-radiotelegrafista que, conforme Luiz Maranhão Filho (1991, p. 8), trabalhara a bordo de um navio brasileiro entre a América do Sul e a Europa:

$\mathrm{Na}$ mesma viagem ao Rio, para licenciar-se da Marinha Mercante, em 1922, Oscar Moreira Pinto levava uma missão; a de estabelecer contato com algumas pessoas que se interessavam pela nova tecnologia, um pouco além do simples evento social de 7 de setembro [...].

Publicada no Diário de Pernambuco, notícia a respeito das irradiações durante a Exposição Internacional do Rio de Janeiro chamara a atenção dos integrantes do Rádio Clube, "então um pouco inativo" no dizer de Maranhão Filho (1991, p. 8). Conforme o mesmo autor, Oscar Moreira Pinto chega a contatar o grupo que, em seguida, iria organizar a Rádio Sociedade do Rio de Janeiro. De Edgard Roquette-Pinto, vem a sugestão de "adaptar um transmissor de telegrafia para fonia e que adquirisse alguns materiais de som que vieram para a exposição e podiam ser comprados ainda no Rio" (MARANHÃO FILHO, 1991, p. 9). Com equipamento francês dos Etablissements Radio Lucien Lévy adaptado para a transmissão sonora, é montada, deste modo, a estação SQIA do Rádio Clube de Pernambuco. De acordo com Luiz Maranhão Filho (1991, p. 9), que se baseia em depoimento de Arnaldo Moreira Pinto ${ }^{9}$ para o Museu da Imagem e do Som de Pernambuco, a primeira irradiação ocorre em fevereiro de 1923, antes, portanto, das realizadas pela Rádio Sociedade. Esta versão diverge da apresentada por Oscar Dubuex Pinto (abr. 1984) e baseada em texto enviado pelos pernambucanos e publicado no número 27 da revista Rádio, em 15 de novembro de $1924^{10}$, que ele reproduz:

Já reorganizado, o Rádio Clube de Per-
nambuco adquiriu terreno à avenida
Cruz Cabugá, 394, em Santo Amaro,
construiu edifício para sua sede e ins-
talações, onde foi montado um nosso
emissor, cujas transmissões foram inau-
guradas no dia 8 de novembro de 1924
[...].

Até que ponto pode se dar crédito ou não a estas informações remanescentes é algo difícil de definir. Aventa-se mesmo um engano de data, frequente em relatos orais de fatos ocorridos tempos antes. E há, obviamente, os dados dando conta de irradiações anteriores de música e, possivelmente, de voz. Em que medida estas se posicionam, em termos mais contemporâneos, como radiotelefonia ou radioamadorismo também se constitui em tarefa das mais arriscadas.

\section{A Rádio Sociedade do Rio de Janeiro}

Boa parte da importância da Rádio Sociedade do Rio de Janeiro deve-se às atitudes e à proeminência em relação aos seus pares de Edgard Roquette-Pinto, sem dúvida um dos principais incentivadores da implantação

9 Irmão de Oscar Moreira Pinto.

10 Trata-se do periódico bimensal e órgão oficial da Rádio Sociedade do Rio de Janeiro. 
deste meio no Brasil. "Era nacionalmente admirado pelo que já fizera pela ciência brasileira", afirma o jornalista Ruy Castro (In: MILANEZ, 2007, p. 54). "A introdução do rádio no país não era, a rigor, apenas a sua segunda ou terceira façanha, e estaria longe de ser a última." Independentemente de a Rádio Sociedade ser a primeira ou não, a erudição, o idealismo e a atividade incessante, talvez, expliquem e, mesmo, justifiquem a atribuição do epíteto "father of the Brazilian radio" (BOJUNGA In: SOARMEC, maio 1990), dado pela imprensa dos Estados Unidos durante uma viagem aquele país, e, à sua época, um senso comum por aqui.

Membro da Academia Brasileira de Ciências, Roquette-Pinto constitui-se, de 1923 a 1936, no principal articulador da Rádio Sociedade do Rio de Janeiro. De fato, por tudo isto, vai se configurar em uma referência para outras entidades semelhantes, que surgem até meados da década de 1920. Prova disto é o já citado contato de Oscar Moreira Pinto, do Rádio de Clube de Pernambuco. Uma consulta às coleções das revistas Rádio e Electron, mantidas em épocas diversas pela Rádio Sociedade do Rio de Janeiro, atesta frequente intercâmbio da Rádio Sociedade com suas congêneres.

Com uma preocupação nitidamente de difusão cultural - embora marcada por certo elitismo - e instigado pelo que vira durante a Exposição Internacional do Rio de Janeiro, Edgard Roquette-Pinto procura mobilizar integrantes da Academia Brasileira de Ciências:

No começo de 1923, desmontava-se a estação do Corcovado e a da Praia Vermelha ia seguir o mesmo destino se o governo não a comprasse. O Brasil ia ficar sem rádio. Ora, eu vivia angustiado com esta história, porque já tinha convicção profunda do valor informativo e cultural do sistema desde que ouvira as transmissões do Corcovado alguns meses antes [...]. Resolvi interessar no problema a Academia de Ciências. Era presidente nosso querido mestre Henrique Morize $^{11}$. Eu era secretário. E foi assim que nasceu a Rádio Sociedade do Rio de Janeiro a 20 de abril de 1923. (ROQUETTE-PINTO In: TAVARES, 1997)

$11 \mathrm{Na}$ realidade, a grafia do nome de Morize foi aportuguesada pelos seus contemporâneos. Ele nasceu na França, em 1860, e chamava-se Henri Charles Morize. Ao longo desta obra, preferiu-se Henrique por ser a forma como o próprio Roquette-Pinto referia-se ao seu colega da Academia Brasileira de Ciências.
Nesta data, de acordo com Maria Elvira Bonavita Federico (1982, p. 34-5), os pioneiros cariocas reúnemse na Academia Brasileira de Ciências, fundando a entidade. Em seguida, pleiteiam e conseguem o empréstimo, durante uma hora por dia, dos transmissores instalados pela Western Electric na Praia Vermelha. Os entusiastas cariocas enfrentam, no entanto, situação semelhante à dos amadores do Rádio Clube, possuidores também de estações particulares de recepção e/ou transmissão consideradas clandestinas com base, no dizer de Roquette-Pinto (1940, p. 73), em "um regulamento anacrônico, carranca, retrógado, infeliz". A única saída é sensibilizar o ministro de Viação e Obras Públicas para que sejam flexibilizadas as normas: "A Academia de Ciências mandou, então, ao ministro Francisco Sá, uma representação que pôs a questão nos seus devidos termos e tão eloquente foi, que abriu através da lei colonial o surto da radiofonia" (ROQUETTE-PINTO, 1940, p. 73-4). Em uma “jogada hábil”, como define Ruy Castro (In: MILANEZ, 2007, p. 73), Roquette-Pinto indica o ministro Francisco Sá para a presidência de honra da Rádio Sociedade:

No dia $1^{\circ}$ de maio, sob vista grossa da autoridade, [...], a Rádio Sociedade fez a sua primeira transmissão experimental pela estação da Praia Vermelha. Às 20 h30 em ponto, Cauby de Araújo, um dos signatários [da ata de criação da entidade], anunciou a declaração de Roquette-Pinto comunicando a fundação da rádio. Roquette tomou o microfone e, com grande otimismo e exagero, disse: "[...] todos os lares espalbados pelo imenso território do Brasil receberão livremente o conforto moral da ciência e da arte pelo milagre das ondas misteriosas que transportam, silenciosamente, no espaço, as harmonias". (CASTRO In: MILANEZ, 2007, p. 73).

Dias depois, o ministro Francisco Sá revogaria a lei, concedendo, de acordo com José Ramos Tinhorão (1981, p. 36), licenças a título precário para o funcionamento de 536 receptores. Usando, mais uma vez, a estação da Praia Vermelha, no dia 19, já com a garantia de uma escuta legalizada, ocorre a instalação solene da Rádio Sociedade na Escola Politécnica, sua primeira sede:

Roquette e seus colegas reunidos na Escola Politécnica, ouviram emociona- 
dos quando, da Praia Vermelha, Edgar Sussekind de Mendonça ${ }^{12}$ abriu a transmissão recitando um soneto do próprio Roquette [...]. Heloísa Alberto Torres ${ }^{13}$, filha do abolicionista Alberto Torres, leu um conto infantil de Monteiro Lobato, de que não há registro do título. E, concluindo, Francisco Venâncio Filho ${ }^{14}$ leu uma página de Os sertões. (CASTRO In: MILANEZ, 2007, p. 73).

Apesar do empenho e do idealismo de Roquette-Pinto e de seus associados, a radiodifusão nasce de maneira precária. Em junho, o poeta e jornalista Amadeu Amaral - simpático à causa de Roquette-Pinto - descreveria em texto publicado em O Estado de São Paulo a simplicidade das instalações iniciais da Rádio Sociedade:

Quando vi a antena plantada a um canto do jardim - uma simples vara de bambu com uns fios ligeiramente instalados - e, sobretudo, quando penetrei no quarto das operações e pude examinar os toscos objetos que completavam o dispositivo, não pude deixar de sorrir por dentro. Não era possível que aquela caranguejola, feita com bambu, alguns metros de fio de cobre, uma bobina de papelão e um fone de aparelho comum, desse resultado sério. Quem sabe se aquilo que pregavam ouvir por intermédio desse aparelho não seriam quaisquer vibrações ordinárias, confusamente conduzidas pelos tais fios expostos!

Dentro em pouco, porém, colocando o fone ao ouvido, pude escutar versos declamados na Praia Vermelha e entremeados de música, tudo tão perceptível como se os sons se originassem a dois passos. Aquela caranguejola ridícula funcionava maravilhosamente... (AMARAL apud ROQUETTE-PINTO, 1927, p. 74).

12 Pedagogo, um dos fundadores da Associação Brasileira de Educação.

13 Iniciou como assistente de Roquette-Pinto no Museu Nacional, desenvolvendo, ao longo do tempo, estudos nas áreas de Antropologia, Arqueologia e Etnografia. Posteriormente, ocupou a direção do museu de 1938 a 1955.

14 Engenheiro e educador.
Já com equipamentos próprios - um transmissor doado pela Casa Pekan, de Buenos Aires, cujo representante no Brasil, M. B. Astrada, era um dos sócio-fundadores -, as irradiações, segundo Ruy Castro (In: MILANEZ, 2007, p. 76), seriam retomadas, apenas, no dia 7 de setembro. No mês seguinte, com data de 15 de outubro, circula a revista Rádio, publicação bimensal dedicada à "divulgação científica geral" e "especialmente consagrada à radiocultura". Conforme Maria Elvira Bonavita Federico (1982, p. 36), o periódico em sua primeira edição registra, entre outras intenções da Rádio Sociedade, a de oferecer "conferências populares de ciência, literatura e arte". Assim, visitam a entidade, entre outros, o físico alemão Albert Einstein, o escritor futurista italiano Filippo Tommaso Marinetti, o general e engenheiro francês Gustave-Auguste Ferrié, a físico-química francesa $\mathrm{Ma}$ rie Curie e o historiador também francês Paul Hazard. É precisa, portanto, a observação de Ruy Castro (In: MILANEZ, 2007, p. 76): “a Rádio Sociedade parecia, a princípio, uma extensão da Academia de Ciências". Nesta linha, o idealismo dos pioneiros da Rádio Sociedade cunha o slogan "Trabalhar pela cultura dos que vivem em nossa terra e pelo progresso do Brasil".

Mesmo bem-intencionada, a programação não atrai grandes parcelas da população, como vai recordar Renato Murce (1976, p. 19-20):

[...] no começo, pretendiam impor o rádio apenas como veículo de um tipo de cultura, com uma programação quase que só de música chamada erudita (da qual quase ninguém gostava), conferências maçantes, palestras destituídas de qualquer interesse, enfim, um rádio sofisticado para meia dúzia de crentes, não atingido a massa.

O magnífico slogan de Roquette-Pinto [...] não permitia que se popularizasse o rádio, tal como ele precisava para se expandir. Nada de publicidade, nada de música popular (em samba, então, nem era bom falar), nada daquilo que, de algum modo, desvirtuasse ou atingisse as boas intenções do programa traçado na famosa divisa.

Assim, os primeiros anos do rádio foram difíceis: muita música clássica, muita ópera, muita conversa fiada e a colaboração graciosa de alguns artistas da
19 
sociedade. Quase todos apresentavam números do mesmo estilo dos discos irradiados.

Na linha do raciocínio de Murce, da segunda metade da década de 1920 até o início dos anos 1930, as emissoras comerciais e a busca constante do lucro vão ocupar o lugar das sociedades e das intenções - louváveis, mesmo que um tanto elitistas - dos pioneiros. Vai ser negociando anúncios e patrocínios, pretensões bem mais mundanas, que o rádio chegará ao grande público.

\section{Considerações finais}

A partir das fontes históricas - o noticiário da época, os poucos documentos e testemunhos remanescentes e/ ou a bibliografia neles baseada - aqui citadas, cabe destacar alguns pontos a respeito da consolidação da ideia de rádio como meio de comunicação ponto-massa e dos protagonistas deste processo. Há que lembrar, como central, uma diferenciação de objetivos entre as indústrias estadunidenses presentes na Exposição Internacional do Rio de Janeiro e os pioneiros organizados tanto no Rádio Clube como na Rádio Sociedade. Enquanto a Westinghouse e a Western visavam, obviamente, ao lucro, aquelas entidades caracterizam-se, como demonstrado, pelo associativismo idealista de elite. Embora, na exposição, as duas indústrias estadunidenses buscassem comercializar, basicamente, equipamentos de radiotelegrafia, radiotelefonia e radiocomunicação, visando como cliente, em especial, ao Ministério de Viação e Obras Públicas, suas demonstrações despertaram e/ou reforçaram, mesmo que junto a um pequeno grupo, o interesse em relação ao uso daquelas tecnologias na comunicação sonora ponto-massa. Em relação ao rádio, o papel da exposição, pode ter sido superestimado na imprensa da época. É possível depreender - inclusive a partir de citações explícitas - intenso trabalho de public relations no noticiário a respeito do pavilhão dos Estados Unidos, de modo geral, e às demonstrações promovidas pela Westinghouse e a Western Electric, em particular.

O Rádio Clube de Pernambuco, como entidade, em fevereiro de 1923, ou alguns de seus sócios, no início da década, podem ter realizado experimentos com irradiações sonoras, portanto anteriores aos da Rádio Sociedade do Rio de Janeiro, cuja primeira transmissão ocorre em $1^{\circ}$ de maio de 1923 . Há pequenas diferenças de objetivos entre os pernambucanos e os cariocas, mas ambas as iniciativas dedicam-se à difusão e à ampliação do conhecimento. O Rádio Clube organiza-se para representar os interesses dos proprietários de estações amadoras de transmissão e recepção, ilegais conforme a legislação da época. O estatuto elaborado em 1919 indica certo predomínio, naquele momento, da radiotelegrafia, o que não descarta a possibilidade de adaptação das estações dos sócios visando receber e transmitir mensagens sonoras. A disseminação do conhecimento parece concentrar-se mais nas questões técnicas relativas ao uso em geral das ondas eletromagnéticas. Nas atividades da Rádio Sociedade do Rio de Janeiro, há claramente uma ideia de difusão do conhecimento e da cultura, mesmo que esta última por um viés elitista e ligado à ciência. A intensa atividade intelectual de Roquette-Pinto e, convém lembrar, o fato de a entidade atuar na então capital federal, podem ter, erroneamente, maximizado o papel da Rádio Sociedade. Observa-se, ainda, que os dados consultados indicam não ter havido constância nas irradiações sonoras tanto do Rádio Clube quanto da Rádio Sociedade.

A respeito do pioneirismo em relação ao rádio meio de comunicação com uma pretensão ponto-massa, opta-se assim por reconhecer como idêntico o papel dos pioneiros do Rádio Clube de Pernambuco e da Rádio Sociedade do Rio de Janeiro. De fato, muito mais relevantes do que a demonstração realizada em 1922 pelo capital estrangeiro. Tem-se a consciência de que, entre um grupo e outro, na época, isto não tinha a menor importância, como atestam as constantes citações à atuação dos pioneiros de Recife nas publicações de seus pares cariocas. Para ambas as entidades, naqueles tempos iniciais, parece valer a definição de Edgard Roquette-Pinto (ELECTRON, 16 mar. 1926, p. 1): "Rádio é o jornal de quem não sabe ler; é o mestre de quem não pode ir à escola; é o divertimento gratuito do pobre; é o animador de novas esperanças; o consolador dos enfermos; o guia dos sãos, desde que o realizem com espírito altruísta e elevado". Diferentes de muitos daqueles que fariam o rádio já negócio, os pioneiros tinham o espírito altruísta e elevado. Por tudo, então, merecem ser valorizados e lembrados. Em um país carente de iniciativas arrojadas e com um pé no futuro, não é esta a atitude mais adequada?

\section{Referências bibliográficas:}

A RADIODIFUSÃO no Brasil. O Observador - Econômico e Financeiro, Rio de Janeiro, ano 3, n. 30, p. 41-55, jul. 1938.

AS NOVIDADES da exposição. Telefone sem fio por meio do radio. A Noite, Rio de Janeiro, 20 maio 1922. p. 6. 
BRITISH BROADCASTING CORPORATION. O rádio no Brasil. Londres: Serviço Brasileiro da BBC, 1988. Série de programas de rádio.

CÂMARA, R. P. da. Fragmentos da história do Rádio Clube de Pernambuco. 2.ed. Recife: Cepe, 1998. 152p.

FEDERICO, M. E. B. História da comunicação: rádio e TV no Brasil. Petrópolis: Vozes, 1982. 170p.

FERRARETTO, L. A. Rádio no Rio Grande do Sul (anos 20, 30 e 40): dos pioneiros às emissoras comerciais. Canoas: Editora da Ulbra, 2002. 258p.

- Rádio - O veículo, a história e a técnica. 3.ed. Porto Alegre: Doravante, 2007. 378p.

Rádio e capitalismo no Brasil: uma abordagem histórica. In: HAUSSEN, D. F.; BRITTOS, V. C. (Org.). Economia política, comunicaşão e cultura: aportes teóricos e temas emergentes na agenda política brasileira. Porto Alegre: Editora da PUCRS, 2009. p. 93-112.

Roberto Landell de Moura: o pioneiro brasileiro das comunicações. In: PONTIFÍCIA UNIVERSIDADE CATÓLICA DO RIO GRANDE DO SUL. In: $11^{\circ}$ Seminário Internacional da Comunicação. Porto Alegre, 16 nov. 2011. 15f. Texto apresentado no Grupo de Trabalho Mídias Sonoras.

HONOLULU gets Rio radio, 8.000 miles away; new Record with antennae between 2 peaks. The New York Times, Nova Iorque, 30 mar. 1923. Disponível em: <http:// query.nytimes.com/>. Acesso em: 20 jul. 2011.

JAMIESON, A. Ainsworth's Latin dictionary. Londres: Moon, Boys \& Graves, 1828. 1.050p.

MARANHÃO FILHO, L. Memória do rádio. Recife: Jangada, 1991. 100p.

MILANEZ, L. (Org.). Rádio MEC: herança de um sonho. Rio de Janeiro: Associação de Comunicação Educativa Roquette-Pinto, 2007. 236p.

MORAES, J. G. de. História do rádio. Rio de Janeiro, 12-23 abr. 2010. Disponível em: < http:/ / fotolog.terra.com.br/ historiadoradio >. Acesso em: 9 ago. 2011.

NOSSO SÉCULO. São Paulo: Abril Cultural, 19801982. 6v.
ORTIZ, R. A moderna tradição brasileira: cultura brasileira e indústria cultural. 5.ed. São Paulo: Brasiliense, 1994. 226p.

OXFORD ENGLISH DICTIONARY. 2.ed. Oxford: Oxford University Press, 2009. CD-ROM.

PINTO, O. D. Rádio Clube de Pernambuco - Notas sobre sua bistória. Rio de Janeiro: abr. 1984. Texto fornecido pelo autor à Fundação Joaquim Nabuco, de Recife (PE).

RÁDIO CLUBE (ASSOCIAÇÃO DE AMADORES DE TSF). Estatuto - Regulamento das estações. recife, 1919. $16 f$.

ROQUETTE-PINTO, E. Alto-falante. Electron, Rio de Janeiro: Rádio Sociedade do Rio de Janeiro, 16 mar. 1926. p. 1.

. Ensaios brasilianos. São Paulo: Companhia Editora Nacional, 1940. 250p. (Brasiliana, 160).

SOCIEDADE DOS AMIGOS OUVINTES DA RÁDIO MEC. Depoimento de Beatriz. Roquette-Pinto Bojunga. Rio de Janeiro, maio 1990. Disponível em: <http:// www.soarmec.com.br/amigo-ouvinte/entrevistas/beatriz5.html/>. Acesso em: 25 jan. 2006.

TAVARES, R. C. Histórias que o rádio não contou. São Paulo: Negócio, 1997. CD.

TELEFONE alto-falante. O Jornal, Rio de Janeiro, 8 set. 1922. p. 10.

TINHORÃO, J. R. Música popular, do gramofone ao rádio e TV. São Paulo: Ática, 1981. 218p. (Ensaios, 69).

UM radiotelefonista. O Jornal, Rio de Janeiro, 14 set. 1922. p. 6.

Recebido: $15 / 08 / 2013$

Aprovado: 23/09/2013

21 